\title{
Pewarisan Saham Warga Negara Asing Pada Perseroan Terbatas Penanaman Modal Asing (PT PMA)
}

\author{
Ni Putu Eka Martini AR ${ }^{1}$ \\ ${ }^{1}$ Program Studi Magister (S2) Kenotariatan Fakultas Hukum Universitas Udayana, \\ E-mail: ekamartini52@gmail.com
}

\begin{tabular}{l}
\hline Info Artikel \\
Masuk :28 Juli 2019 \\
Diterima : 16 Agustus 2019 \\
Terbit : 30 Desember 2019 \\
Keywords : \\
Inheritance of Shares; heirs; \\
Foreign Capital Investment \\
Company \\
Corresponding Author; \\
Eka Martini; E-mail: \\
ekamartini52@gmail.com \\
10.24843/ AC.2019.v04.i03.p03 \\
Pewarisan Saham; Ahli Waris; \\
Asing \\
Perusahaan Penanaman Modal \\
\end{tabular}

\begin{abstract}
Share ownership in a Foreign Capital Investment Company owned by a foreign nationality could be inherited to its legal heirs if the owner dies, in this case both the testator and the heir are foreign citizens. Inheritance of shares to his heirs must be based on a written document. Normatively the transfer of shares due to inheritance is based on Article 57 paragraph (2) of Law Number 40 Year 2007, but the mechanism of inheritance of shares is not explicitly regulated so it is an empty norm and legal construction is required. The purpose of this study is to determine the inheritance of shares in a Foreign Capital Investment Company whom the testator and the heir are fellow foreign nationals, and regarding the enforcement of foreign documents in inheritance of shares. By looking at the norms problem, the method used is a library technique with a statutory and conceptual approach. The results of the study concluded that the inheritance of shares in a Foreign Capital Investment Company is subject to the laws in force in Indonesia, while the determination on stipulation of the heirs of the testator who are fellow foreign citizens must follow the laws of the country concerned and evidenced by the existence of written documents. The application of foreign documents in the inheritance of shares in Indonesia shall full fill the requirements as regulated in Minister of Foreign Affairs Regulation Number 09/A/KP/XII/2006/01 that must be legalized at the Embassy of the Republic of Indonesia previously.
\end{abstract}

\begin{tabular}{l} 
Abstrak \\
\hline Kepemilikan saham pada Perseroan Terbatas Penanaman Modal \\
asing yang dimiliki perseorangan berkewarnegaraan asing, dapat \\
diwariskan kepada ahli warisnya yang sah apabila pemiliknya \\
meninggal dunia, yang dalam hal ini baik pewaris dan ahli \\
warisnya merupakan warga negara asing. Pewarisan saham \\
kepada ahli warisnya harus didasarkan pada suatu dokumen \\
tertulis. Secara normative peralihan saham karena pewarisan \\
didasarkan pada Pasal 57 ayat (2) Undang-Undang Nomor 40 \\
Tahun 2007, akan tetapi mekanisme pewarisan saham tidak \\
diatur secara ekplisit sehingga merupakan suatu norma kosong \\
dan perlu dilakukan konstruksi hukum. Tujuan dari penelitian \\
ini yaitu untuk mengetahui pewarisan saham pada Perseroan \\
Terbatas Penanaman Modal Asing yang pewaris dan ahli \\
warisnya sesama warga negara asing, serta mengenai \\
pemberlakukan dokumen asing dalam pewarisan saham. Dengan \\
mencermati permasalahan norma, maka metode yang digunakan \\
adalah teknik kepustakaan dengan pendekatan perundang-
\end{tabular}


undangan dan konseptual. Hasil dari penelitian menyimpulkan bahwa pewarisan saham pada Perseroan Terbatas Penanaman Modal Asing tunduk pada hukum yang berlaku di Indonesia, sedangkan penentuan mengenai penetapan ahli waris dari pewaris yang sesama warga negara asing harus mengikuti hukum dari negara yang bersangkutan dan dibuktikan dengan adanya dokumen tertulis. Pemberlakuan dokumen asing dalam pewarisan saham di Indonesia harus memenuhi persyaratan sebagaimana diatur dalam Peraturan Menteri Luar Negeri Nomor 09/A/KP/XIL/2006/01 yaitu harus dilegalisasi terlebih dahulu di Kedutaan Besar Republik Indonesia.

\section{Pendahuluan}

Keberadaan investasi asing dapat dilihat melalui eksistensi Perseroan Terbatas dalam bentuk Perseroan Terbatas Penanaman Modal Asing. Masuknya penanam modal asing akan dapat menstimulasi pertumbuhan ekonomi ${ }^{1}$ dan membuka lapangan pekerjaan. Unsur yang harus dimiliki untuk menjadi Perseroan Terbatas suatu perseroan sangat ditentukan oleh pemegang sahamnya.

Warga negara asing dapat diartikan sebagai orang yang menetap di suatu negara dengan tujuan tertentu, akan tetapi tidak teregistrasi sebagai warga negara tersebut dan masih tercatat di negara lain. Status kewarganegaraan pemegang sahamnya merupakan faktor yang akan berpengaruh pada status permodalan suatu perseroan, apakah akan menjadi Penanaman Modal Dalam Negeri atau Penanaman Modal Asing. ${ }^{2}$ Manakala pewarisan saham suatu perseroan sedangkan pewaris dan ahli warisnya berstatus Warga Negara Asing, maka hukum yang diterapkan atas pewarisan tersebut adalah hukum dari negara yang bersangkutan berasal.

Akibat dari adanya kematian sebagai suatu peristiwa hukum, nantinya akan akan ditetapkan siapa saja yang bersatus sebagai ahli waris atas meninggalnya seseorang. Peninggalan seseorang yang meninggal dunia dengan mewariskan sejumlah harta berupa uang, tanah, properti, ataupun saham diatur secara khusus dalam hukum waris. Sebelum harta warisan dibagi, apabila tidak ada surat wasiat, biasanya akan diawali dengan menentukan ahli warisnya atas harta peninggalan tersebut. Penanaman Modal Asing yakni adanya unsur kepemilikan modal asing dalam komposisi para pemegang sahamnya, baik seluruhnya maupun sebagian atas saham di perseroan. Oleh karena itu, Perseroan Terbatas Penanaman Modal Asing tidak hanya tunduk pada Undang-Undang Penanaman Modal tetapi Undang-Undang Perseroan Terbatas. Adapun pemilik suatu perseroan tidak hanya dari warga negara asing secara perseorangan, tetapi juga badan hukum asing yang terdaftar di negaranya serta Perseroan Terbatas Penanaman Modal Asing yang didirikan di Indonesia. Oleh karena itu status Oleh karena itu, disinilah pentingnya keberadaan dari suatu dokumen tertulis yang dapat membuktikan siapa saja yang berstatus sebagai ahli waris pewaris berdasarkan hukum yang berlaku baginya. Apabila pewaris dan ahli waris adalah warga negara asing maka dalam menetapkan ahli warisnya harus berdasarkan hukum

\footnotetext{
${ }^{1}$ Abib, Agus Saiful, Pujiastut, Endah, dan Mulyani, Tri, (2017), Konsep Penanaman Modal Sebagai Upaya Menstimulasi Peningkatan Perekonomian Indonesia, Jurnal Humani, 7 (1), h.1.

2 Zaharani, Fagustien, (2018), Pewarisan Saham Perseroan Terbatas Kepada Warga Negara Asing Melalui Surat Wasiat, Jurnal Res Judicata, 1(2), h. 78.
} 
waris dari negara yang bersangkutan walaupun yang menjadi objek warisan berada di Indonesia. Oleh karena saham perseroan dapat dipindahtangankan maupun diwariskan, maka perubahan komposisi para pemegang saham pada suatu perseroan cukup dengan mengganti struktur kepemilikannya saja ${ }^{3}$ tanpa harus membubarkan atau membentuk perusahaan baru.

Saham merupakan bukti kepemilikan bagi pemiliknya ${ }^{4}$ dan disamakan dengan nilai mata uang. Wujud saham sendiri berupa lembaran sertifikat yang didalamnya mencantumkan nama pemilik dan nama perusahaan ${ }^{5}$ yang menerbitkannya. Berdasarkan Pasal 511 angka 4 KUHPerdata menyatakan bahwa "sero-sero atau andilandil dalam persekutuan perdagangan uang, persekutuan dagang atau persekutuan perusahaan, sekalipun benda-benda persekutuan yang bersangkutan dan perusahaan itu adalah kebendaan tidak bergerak." Berdasarkan hal tersebut maka pada Pasal 60 ayat (2) Undang-Undang Perseroan Terbatas bahwa "saham sebagai benda bergerak dapat diagunkan dengan gadai atau jaminan fidusia sepanjang tidak ditentukan lain dalam anggaran dasar." Dalam prakteknya hampir tidak pernah ditemukan jaminan fidusia saham, tetapi lebih sering menggunakan gadai saham. Berdasarkan konsep dominium plenum $^{6}$ berarti pemilik sahamlah yang mempunyai hak suara dan walaupun saham tersebut digadaikan, bukan berarti hak suara nya juga berpindah tetapi tetap melekat pada pemiliknya.

Pemegang saham selaku pemilik atas sejumlah saham memiliki hak kebendaan atas saham-sahamnya. Dalam struktur organ perusahaan, pemegang saham berkedudukan sebagai pemilik atas perusahaan tersebut yang menimbulkan hak dan kewajiban. ${ }^{7}$ Hubungan perikatan yang muncul dalam suatu perseroan diatur lebih lanjut dalam Undang-Undang Perseroan Terbatas dan Anggaran Dasar/Anggaran Rumah Tangga Perseroan. Meninggalnya pemegang saham tidak mempengaruhi legalitas eksistensi kehidupan perseroan.

Dalam hal mengenai terjadinya pewarisan saham, maka penting untuk memahami bagaimana mekanisme yang harus ditempuh untuk dapat mengalihkan kepemilikan sahamnya kepada ahli warisnya. Hal ini diperlukan untuk memberikan posisi pemegang saham kepada ahli warisnya sehingga ia dapat menggunakan hak suaranya guna mencapai tujuan perseroan. Berkaitan dengan terjadinya kekosongan norma dalam artikel ini yaitu Pasal 57 ayat (2) Undang Undang Perseroan Terbatas menyatakan, "persyaratan sebagaimana dimaksud pada ayat (1) tidak berlaku dalam hal pemindahan hak atas saham disebabkan peralihan hak karena hukum, kecuali keharusan sebagaimana dimaksud pada ayat (1) huruf (c) berkenaan dengan kewarisan." Ketentuan Pasal 57 ayat (2) Undang-Undang No. 40 Tahun 2007 tersebut

\footnotetext{
${ }^{3}$ Subianto, Deri Andrias, dan Asrori, M. Hudi, (2019), Status Perseroan Terbatas Penanaman Modal Asing Akibat Dikabulkannya Pewarganegaraan Para Pemegang Saham, Jurnal Repertorium, 6 (1), h. 14.

${ }^{4}$ Hapsari, Alya, Priandhini, Liza dan Suyandono, Widodo (2019), Pemberian Akta Hibah Wasiat Atas Seluruh Saham Perseroan PT LNI, Jurnal Fakultas Hukum Universitas Indonesia, 1(2), h. 2.

${ }^{5}$ Savitri, Yuni, (2012), Implementasi Peraturan Pemerintah Terkait Dengan Kepemilikan Saham Dari Modal Asing, Unness Law Journal, 1 (1), h. 31.

${ }^{6}$ Wicaksono, Lucky Suryo, (2016), Kepastian Hukum Nominee Agreement Kepemilikan Saham Perseroan Terbatas, Jurnal Hukum Ius Quia Iustum, 23 (1), h. 51-52.

${ }^{7}$ Haryono, Wenny Ayu, (2016), Perlindungan Hukum Terhadap Pemegang Saham Minoritas Dalam Peralihan Saham Dengan Akta Pengakuan Hutang, Jurnal IUS, 4(3), h. 400
} 
tidak secara tegas mengatur mengenai mekanisme prosedural terjadinya peralihan saham karena pewarisan, sehingga menyebabkan normanya menjadi kosong. Hal ini senada dengan simpulan dalam jurnal yang berjudul "Saham Sebagai Objek Pewarisan Ditinjau Dari Undang-Undang Nomor 40 Tahun 2007 tentang Perseroan Terbatas" bahwa saham sebagai objek waris dapat beralih karena adanya pewarisan yang diterangkan secara implisit dalam Pasal 57.8 Maka dari itu perlu untuk dilakukan penemuan hukum secara argumentum a contrario mengenai bagaimana mekanisme peralihan saham yang terjadi karena pewarisan yang berbeda dengan peralihan hak saham karena proses jual-beli.

Peralihan saham kepada warga negara asing karena pewarisan pada Perseroan Terbatas Penanaman Modal Asing sangat penting untuk memperhatikan batasan modal asing yang dapat dimiliki, sehingga tidak melebihi ketentuan maksimum yang diperbolehkan. Apabila perseroan tersebut merupakan Penanaman Modal dalam Negeri, setelah beralih kepada ahli waris warga negara asing maka status dari perseroan tersebut akan berubah menjadi Penanaman Modal Asing. Hasil penelitian yang dilakukan oleh Amadeo Tito Sebastian menyimpulkan bahwa kewarganegaraan seseorang tidak menghalangi hak menjadi ahli waris. ${ }^{9}$ Sebelum Peraturan Pemerintah Nomor 24 Tahun 2018 diberlakukan, proses peralihan saham kepada warga negara asing harus mendapat persetujuan Badan Koordinasi Penanaman Modal lebih dahulu yang kemudian akan digunakan oleh notaris sebagai dasar dalam membuat akta perseroan atas perubahan nama pemegang sahamnya. Setelah peraturan pemerintah tersebut diberlakukkan, pewarisan saham kepada warga negara asing tidak diperlukan lagi persetujuan dari Badan Koordinasi Penanaman Modal tetapi cukup dilakukan pembaharuan nama pemegang sahamnya melalui Online System Submission dengan berdasarkan akta notaris. Oleh karena itu pewarisan saham kepada warga negara asing saat ini telah mengalami perubahan secara drastis dalam hal lembaga yang berwenang sehingga layak untuk diteliti.

Berdasarkan fakta-fakta tersebut, oleh karenanya peneliti merasa perlu untuk meneliti yang berkaitan dengan pewarisan saham pada orang asing atas perusahaan yang didirikan berdasarkan hukum Indonesia. Tujuan yang ingin dicapai dalam penelitian ini yaitu mengetahui pewarisan saham pada Perseroan Terbatas Penanaman Modal Asing yang pewaris dan ahli warisnya merupakan warga negara asing serta untuk mengetahui pemberlakuan dokumen asing dalam pewarisan saham. Untuk itu peneliti ingin mengangkat penelitian dengan judul "Pewarisan Saham Warga Negara Asing Pada Perseroan Terbatas Penanaman Modal Asing."

\section{Metode Penelitian}

Metode penelitian yang digunakan adalah penelitian hukum normatif, penelitian yang mengkaji permasalahan norma yang dalam artikel ini adanya kekosongann norma pada Pasal 57 ayat (2) Undang-Undang Nnomor 40 Tahun 2007 berkaitan mengenai

\footnotetext{
8 Indah Sari, Ida Ayu Putu Widya dan Ni Wayan Sukeni, (2015), Saham Sebagai Objek Pewarisan Ditinjau Dari Undang-Undang Nomor 40 Tahun 2007 tentang Perseroan Terbatas, Jurnal Kertha Semaya, 3(3), E-ISSN:2303-0569.

${ }^{9}$ Sebastian, Amadeo Tito dan Adjie Habib, (2018), Hak Ahli Waris Warga Negara Asing Atas Objek Waris Berupa Saham Perseroan Terbatas Penanaman Modal Dalam Negeri, Jurnal Al'Adl, 10 (2), h. 143.
} 
mekanisme pewarisan hak atas saham karena pewarisan. Dikatakan normatif karena hukum itu diasumsikan sebagai sesuatu yang otonom ${ }^{10}$.

Sumber bahan hukum yang digunakan dalam penelitian ini adalah bahan hukum primer berupa peraturan perundang-undangan, bahan hukum sekunder berupa bukubuku dan jurnal, sedangkan bahan hukum tertier berupa kamus, majalah maupun web internet.

Pendekatan yang digunakan dalam penelitian ini adalah pendekatan pendekatan perundang-undangan dan pendekatan konseptual. Pendekatan perundang-undangan dilakukan dengan menelaah semua peraturan perundang-undangan yang berkaitan dengan pewarisan saham pada Perseroan Terbatas Penanaman Modal Asing dan pemberlakukan dokumen asing di Indonesia. Pendekatan konseptual didasarkan pada dokrin-dokrin dan pandangan-pandangan yang berkembang dalam ilmu hukum. Dengan pandangan-pandangan tersebut peneliti akan menemukan ide-ide yang berkaitan dengan proses pewarisan saham yang ditafsirkan secara sistematis sebagai akibat dari adanya kekosongan norma. Metode pengumpulan bahan hukum dilakukan melalui studi kepustakaan yang dianalisis secara kualitatif.

Dalam penelitian ini, semua bahan tersebut dianalis dengan menggunakan teknik analisa deskripsi dalam menggambarkan kasus, penemuan hukum (rechvinding) dalam menyelesaikan suatu norma kosong, dan argumentasi sebagai penentu dalam menyimpulkan hasil penelitian yang didasarkan pada logika hukum.

\section{Hasil dan Pembahasan}

\subsection{Pewarisan Saham Pada Perseroan Terbatas Penanaman Modal Asing}

Pewarisan merupakan proses pengalihan harta peninggalan. Hubungan hukum lain dari si yang meninggal seperti dalam lapangan hukum keluarga (kekuasaan orang tua, perwalian dan sebagainya) tidak termasuk dalam pewarisan akan tetapi diatur dalam hukum waris. Dalam hukum waris akan diatur mengenai bagaimana pembagian harta peninggalan pewaris ${ }^{11}$ kepada ahli warisnya. Apabila pewaris dan ahli warisnya berkewarganegaraan asing, maka hukum waris yang digunakan akan mengikuti hukum yang berlaku dinegaranya. Hal ini didasarkan konsep bahwa hukum yang berlaku didasarkan pada kewarganegaraan seseorang yang disebut asas personalitas.

Dalam pewarisan, terdapat unsur-unsur penting yang harus dipenuhi supaya proses pewarisan dapat dilakukan, yaitu:

1) Pewaris (Erflater)

Pasal 830 KUHPerdata bahwa "pewarisan hanya berlangsung karena kematian". Pewarisan baru terbuka setelah adanya peristiwa kematian.

2) Ahli waris (Erfgenaam).

Pasal 874 KUHPerdata menyatakan bahwa "seseorang yang dapat menjadi ahli waris adalah orang yang masih hidup saat kematian pewaris dan oleh hukum

10 Barus, Zulfadli, (2013), Analisis Filosofis Tentang Peta Konseptual Penelitian Hukum Normatif Dan Penelitian Hukum Sosiologis, Jurnal Dinamika Hukum, 13 (2), h. 311.

11Suryaningtyas, Agustina, (2018), Pelaksanaan Pembagian Warisan Berdasarkan KUHPerdata Berkenaan Dengan Adanya Testamen, Jurnal Daulat Hukum, 1(1), h. 206 
diberi hak untuk menerima harta peninggalan yang ditinggalkan oleh pewaris". Ahli waris menurut KUHPerdata dapat dibedakan menjadi yaitu ahli waris abintestato dan ahli testamentair erfrecht.

3) Harta peninggalan (erfenis tialatemchap).

Harta peninggalan pewaris yang mempunyai nilai ekonomi. Boedel harta warisan (boedel waris) baru terbuka ketika syarat kematian sudah terjadi (Pasal 830 KUHPerdata). Harta peninggalan tersebut harus dihitung dalam keadaan bersih.

Apabila keberadaan ahli waris tidak ada, maka negara dapat mengambil alih seluruh harta peninggalan tersebut karena dianggap tidak ada pemiliknya. Apabila ahli warisnya tidak bersedia, maka ia dapat melakukan penolakan atas harta warisan sebagaimana disebutkan dalam Pasal 1058 KUHPerdata bahwa "seorang ahli waris juga diberikan hak untuk menolak harta warisan" sehingga dianggap tidak pernah ada. Penolakan terhadap harta warisan tersebut dapat berlaku surut. "Penolakan terhadap warisan tersebut harus dinyatakan dengan tegas dikepaniteraan Pengadilan Negeri" sebagaimana diatur dalam Pasal 1057 KUHPerdata. Oleh karena itu sebaiknya penolakan tersebut harus dilakukan dalam bentuk tertulis. Penolakan tersebut harus berdasarkan keinginan sendiri dari ahli warisnya, bukan karena unsur paksaan atau tipuan, akan tetapi alasan penolakan tersebut tidak boleh dilakukan dengan alasan tidak bersedia membayar hutang-hutang yang menjadi bagian dari harta peninggalan pewaris.

Perseroan Terbatas Penanaman Modal Asing merupakan bentuk badan usaha yang terdapat unsur kepemilikan asing yang pendiriannya tunduk pada hukum yang berlaku dan berada di dalam wilayah Indonesia. Penyertaan modal pada perseroan umumnya berbentuk saham sehingga saham sebagai objek dari pewarisan maka hukum yang diberlakukan adalah hukum Indonesia terlepas apapun kewarganegaraan pemegang sahamnya.

Secara umum apabila suatu perusahaan ingin memindahkan hak atas saham, persyaratan mengenai pemindahan harus dilalui sebagaimana diatur dalam Pasal 57 ayat (1) Undang-Undang Nomor 40 Tahun 2007 yakni:

a) "keharusan menawarkan terlebih dahulu kepada pemegang saham dengan klasifikasi tertentu atau pemegang saham lainnya;

b) keharusan mendapatkan persetujuan terlebih dahulum dari organ perseroan; dan atau;

c) keharusan mendapatkan persetujuan terlebih dahulu dari instansi yang berwenang sesuai dengan ketentuan peraturan perundang-undangan."

Peralihan hak atas saham karena pewarisan pada Pasal 57 ayat (2) Undang-Undang Nomor 40 Tahun 2007 menyebutkan "persyaratan sebagaimana dimaksud ayat (1) tidak berlaku dalam hal pemindahan hak atas saham disebabkan peralihan hak karena hukum kecuali keharusan sebagaimana dimaksud pada ayat (1) huruf c berkenaan dengan kewarisan." Mengenai mekanisme atau prosedur peralihan hak karena pewarisan tidak dijelaskan secara tegas baik pasal-pasal lainnya dalam UndangUndang Perseroan Terbatas maupun peraturan pelaksana dibawahnya. Oleh karena itu dalam menentukan pengaturan pewarisan saham perlu dilakukan konstruksi hukum melalui metode argumentum a contrario. Metode penemuan hukum ini akan mengedepankan cara penemuan hukum yang berlawanan pengertiannya antara 
peristiwa konkret yang dihadapi dengan peristiwa yang diatur dalam undang-undang atau dengan kata lain metode ini menitikberatkan pada ketidaksamaan peristiwanya. Dengan mempersempit perumusan hukum atau perundang-undangan yang ada, tujuannya ialah untuk lebih memberikan kepastian hukum dalam pelaksananaan suatu peraturan sehingga tidak menimbulkan keraguan dalam pelaksanaanya. Oleh karena itu, dengan mengacu pada ketidaksamaan pada proses pengalihan hak atas saham sebagaimana diatur dalam Pasal 57 ayat (1) UU 40/2007 yaitu keharusan menawarkan terlebih dahulu kepada pemegang saham dengan klasifikasi tertentu atau pemegang saham lainya, keharusan mendapatkan persetujuan terlebih dahulu dari organ perseroan, dan/atau keharusan mendapatkan persetujuan terlebih dahulu dari instansi yang berwenang sesuai dengan ketentuan peraturan perundang-undangan, maka proses peralihan hak atas saham karena pewarisan, keharusan dalam peralihan hak atas saham pada Pasal 57 ayat (1) huruf a dan b menjadi tidak berlaku kecuali huruf $c$, proses pengalihan hak atas saham karena pewarisan dalam prakteknya cukup dilakukan dengan adanya turun waris yang berarti mengalihkan nama kepemilikan hak atas saham (balik nama) dari pewaris (yang meninggal) ke ahli warisnya. Pengalihan hak atas saham tersebut harus didukung oleh dokumen-dokumen yang dapat membuktikan bahwa yang bersangkutan merupakan ahli waris yang sah.

Berdasarkan Pasal 830 KUHPerdata yang menyatakan "pewarisan hanya berlangsung karena kematian." Dalam Pasal 832 KUHPerdata bahwa "menurut undang-undang yang berhak untuk menjadi ahli waris ialah para keluarga sedarah, baik sah maupun luar kawin dan si suami atau istri yang hidup terlama, semua menurut peraturan tertera di bawah ini." 12 Apabila kita dikaitkan dengan peralihan saham karena pewarisan maka hak atas saham sebagai harta warisan telah terbuka untuk ahli warisnya sejak kematian pewaris dan proses peralihan saham pada Pasal 57 ayat (1) Undang-Undang Nomor 40 Tahun 2007 berupa "keharusan menawarkan terlebih dahulu kepada pemegang saham dan keharusan mendapatkan persetujuan terlebih dahulu dari organ perseroan" tidak diperlukan dalam pewarisan.

Setelah harta warisan terbuka, maka sesuai Pasal 56 ayat (3) Undang-Undang Nomor 40 Tahun 2007, "Direksi wajib mencatat pemindahan hak atas saham, tanggal, dan hari pemindahan hak tersebut dalam daftar pemegang saham atau daftar khusus dan memberitahukan perubahan susunan pemegang saham kepada Menteri untuk dicatat dalam daftar Perseroan paling lambat 30 (tiga puluh) hari terhitung sejak tanggal pencatatan pemindahan hak." Dalam tahap ini terjadi peralihan hak atas saham karena pewarisan yang awalnya tertulis atas nama pewaris kemudian diganti menjadi nama ahli waris atau disebut juga turun waris saham. Pencatatan tersebut hanya dapat dilakukan melalui Sistem Administrasi Badan Hukum. Sistem ini merupakan bentuk pelayanan yang disediakan oleh pemerintah kepada masyarakat berkaitan dengan pengurusan administrasi badan hukum yang diselenggarakan oleh Direktorat Jenderal Administrasi Hukum Umum dibawah Kementerian Hukum dan Hak Asasi Manusia melalui penerapan teknologi informasi dan komunikasi via komputer dan internet. ${ }^{13}$

Setelah tahap pencatatan maka selanjutnya akan melakukan penyesuaian dalam Online Single Submission. Keberadaan Online Single Submission dipayungi oleh Peraturan Pemerintah Nomor 24 Tahun 2018. Apabila suatu perseroan belum memiliki Nomor

\footnotetext{
${ }^{12}$ Irma Devita Purnamasari, 2012, Kiat-Kiat Cerdas, Mudah, dan Bijak Memahami Masalah Hukum Waris, Kaifa, Jakarta, h. 1-12

${ }^{13}$ Iswi Hariyani, et all, 2011, Panduan Praktis SABH, Pustaka Yustisia, Jakarta, h. 161.
} 
Induk Berusaha dan ijin-ijin lainnya, maka cukup dengan dilakukan penarikan data dari Administrasi Hukum Umum secara online yang akan muncul berdasarkan akta terakhir perseroan. Apabila perseroan sudah memiliki Nomor Induk Berusaha yang masih terekam dengan komposisi pemegang saham yang lama maka harus dilakukan penyesuaian melalui menu Perubahan Akta di akun Online Single Submission perseroan. Penyesuaian dilakukan oleh pelaku usaha untuk memperbaharui data perusahaan sesuai dengan perubahan akta yang telah dilakukan di Sistem Administrasi Badan Hukum melalui Direktorat Jenderal Administrasi Hukum Umum.

Selanjutnya dengan mengacu pada Pasal 5 ayat (1) Peraturan Badan Koordinasi Penanaman Modal Nomor 6 Tahun 2018 menyatakan bahwa "Perusahaan yang akan memulai usaha terlebih dahulu memiliki NIB dan Perizinan Berusaha sesuai dengan ketentuan peraturan perundang-undangan, sedangkan ayat (3) menyebutkan bahwa dalam hal Perusahaan yang telah memiliki izin prinsip, izin investasi, pendaftaran penanaman modal, atau Izin Usaha, yang masih berlaku, permohonan layanan perizinan lain yang diperlukan harus mencantumkan Nomor Induk Berusaha sebagai persyaratan." Nomor Induk Berusaha berfungsi sebagai tanda daftar perusahaan yang berlaku untuk seluruh badan usaha di Indonesia yang pendataannya bersifat terpusat. Khusus pada Perseroan Terbatas Penanaman Modal Asing maka berlaku ketentuan Pasal 6 ayat (3) Peraturan Badan Koordinasi Penanaman Modal Nomor 6 Tahun 2018 menyatakan bahwa "Perusahaan PMA sebagaimana dimaksud pada ayat (1), kecuali ditentukan lain oleh peraturan perundang-undangan, harus memenuhi ketentuan nilai investasi, yaitu:

a. total nilai investasi lebih besar dari Rp10.000.000.000,00 (sepuluh miliar rupiah), diluar tanah dan bangunan;

b. nilai modal ditempatkan sama dengan modal disetor, paling sedikit Rp 2.500.000.000,00 (dua miliar lima ratus juta rupiah);

c. persentase kepemilikan saham dihitung berdasarkan nilai nominal saham; dan

d. nilai nominal saham sebagaimana dimaksud dalam huruf c, untuk masingmasing pemegang saham paling sedikit Rp 10.000.000,00 (sepuluh juta rupiah)."

Berdasarkan ketentuan inilah yang menjadi salah satu pembeda antara Perseroan Terbatas Penanaman Modal Asing dengan Perseroan Terbatas Penanaman Modal Dalam Negeri dari segi jumlah modal. Hal ini merupakan upaya pemerintah dalam menyaring calon pemodal asing yang akan masuk serta memproteksi pelaku usaha dalam negeri yang diharapkan dapat mengisi ruang-ruang kosong sebagaimana ditetapkan dalam Daftar Negatif Investasi guna meningkatkan daya saing pelaku usaha dalam negeri, sehingga tidak semua investor asing dapat masuk untuk berinvestasi di Indonesia. Posisi pemerintah dalam bidang penanaman modal dapat diibaratkan dua mata pisau yakni disatu sisi pemerintah masih membutuhkan investasi asing untuk menunjang pertumbuhan ekonomi, dan disisi lain pemerintah juga dituntut untuk melindungi penanam modal dalam negeri agar dapat terus tumbuh dan berkembang. Oleh karenanya pengawasan dalam penanaman modal memang seharusnya bersifat selaras antara pusat dengan daerah untuk dapat mendata dan mengetahui berbagai permasalahan yang dihadapi oleh penanam modal selama melakukan investasi di Indonesia. Hal ini akan dapat dijadikan pedoman bagi pemerintah dalam melakukan perbaikan-perbaikan dalam kegiatan pembangunan 
serta menjembatani kepentingan-kepentingan dari penanam modal dalam negeri dengan penanam modal asing tanpa merugikan salah satu pihak.

Berdasarkan pemaparan diatas, maka mekanisme yang harus ditempuh dalam proses pewarisan saham yaitu, melakukan pencatatan yang dilakukan oleh Direktur atas terjadinya peralihan hak atas saham karena kewarisan kepada ahli warisnya beradasarkan Pasal 833 KUHPerdata. Kemudian ditindaklanjuti dengan pelaporan ke Kementerian Hukum Dan Hak Asasi Manusia melalui Sistem Administrasi Badan Hukum. Setelah nama pemegang saham berubah menjadi atas nama ahli waris, maka dilakukan penyesuaian di Online Single Submission. Apabila seluruh tahapan sebagaimana disebutkan diatas telah diikuti, maka proses peralihan hak atas saham karena pewarisan barulah dapat dikatakan selesai. Hal ini penting guna menciptakan tata kelola administrasi perusahaan yang baik dengan berdasarkan data berbasis teknologi.

\subsection{Pemberlakuan Dokumen Asing Dalam Pewarisan Saham di Indonesia}

Dalam dunia bisnis yang semakin berkembang, peristiwa-peristiwa hukum yang melibatkan antar subjek hukum dari negara satu dengan negara lainnya semakin meningkat. Penanam modal asing baik itu untuk membentuk suatu perseroan terbatas ataupun hanya bentuk kerja sama secara operasional diwilayah Indonesia dalam melakukan hubungan hukum memerlukan adanya lalu lintas dokumen antar negara. Dokumen tersebut dapat berupa dokumen yang dikeluarkan di Indonesia untuk dipergunakan di luar negeri maupun dokumen asing yang dikeluarkan oleh negara lain untuk dipergunakan di wilayah Indonesia.

Proses pewarisan saham yang pewaris dan ahli warisnya merupakan warga negara asing pada Perseroan Terbatas Penanaman Modal Asing yang berkedudukan di Indonesia maka ada 2 (dua) hukum yang berlaku yaitu dalam hal penetapan ahli waris menggunakan hukum negara pewaris dan ahli warisnya berasal mengingat bahwa hukum perorangan melekat pada subyeknya. Untuk itu maka diperlukan adanya suatu dokumen sebagai bukti tertulis yang dikeluarkan oleh negara pewaris dan ahli warisnya berasal. Dalam hal proses atau mekanisme peralihan hak atas saham dari pewaris kepada ahli warisnya maka harus tunduk pada hukumdi Indonesia. Oleh karena itu, notaris perlu memahami pemberlakuan dokumen asing agar dapat berlaku dan digunakan sebagai dasar dalam pembuatan suatu akta peralihan hak untuk kepentingan perseroan tersebut.

Berdasarkan Peraturan Menteri Luar Negeri No. 09/A/KP/XII/2006/01 “....untuk memberlakukan dokumen asing di Indonesia harus memenuhi syarat yaitu dokumendokumen asing yang diterbitkan di luar negeri dan ingin dipergunakan di wilayah Indonesia harus melalui prosedur yang sama yaitu dilegalisasi oleh Kementerian Kehakiman dan/atau Kementerian Luar Negeri negara yang dimaksud dan Perwakilan Republik Indonesia di negara setempat." Sebaliknya juga berlaku "....jika dokumen yang dibuat di Indonesia hendak diberlakukan di negara asing, harus memenuhi persyaratan yaitu dokumen yang dibuat atau diterbitkan di Indonesia termasuk di daerah dan akan dipergunakan di negara lain harus dilegalisasi oleh Departemen Hukum dan Hak Asasi Manusia, Departemen Luar Negeri RI, dan Perwakilan RI di luar Negeri." Oleh karenanya, pihak notaris dapat menolak dokumen asing yang tidak atau belum dilegaliliasasi. 
Pada Bab VI angka (68) Peraturan Menteri Luar Negeri Nomor 09/A/KP/XII/2006/01 menjelaskan bahwa "legalisasi adalah pengesahan terhadap dokumen dan hanya dilakukan terhadap tanda tangan dan tidak mencakup kebenaran isi dokumen." Oleh karenanya penanggung jawab isi dari dokumen asing tersebut adalah instansi yang mengeluarkannya.

Selain itu, dalam Rumusan Hukum Hasil Rapat Pleno Kamar Mahkamah Agung Republik Indonesia Tahun 2012 halaman 13, menerangkan mengenai proses Legalisasi dokumen asing agar dapat diterima sebagai alat bukti pada peradilan di Indonesia yaitu “....sertifikat atau dokumen asing lainnya sebagai alat bukti harus memenuhi syarat-syarat legalisasi baik dari negara asalnya maupun di Indonesia, dan disamping itu juga harus diterjemahkan oleh seorang penerjemah resmi dan disumpah di Indonesia. Dokumen asing harus dilegalisir oleh Notaris Publik di negara yang bersangkutan dan disahkan oleh Konsulat Jenderal Republik Indonesia di negara setempat."

Penerjemah tersumpah dalam Pasal 1 angka (1) Peraturan Menteri Hukum dan Hak Asasi Manusia Nomor 29 Tahun 2016 menjelaskan "Penerjemah Tersumpah merupakan orang atau individu yang mempunyai keahlian dalam melakukan terjemahan, yang telah diangkat sumpah oleh menteri yang menyelenggarakan urusan pemerintahan di bidang hukum dan hak asasi manusia dan terdaftar pada Kementerian yang menyelenggarakan urusan pemerintahan di bidang hukum dan hak asasi manusia." Oleh karenanya keberadaan dari penerjemah tersumpah sangatlah penting dan akan selalu dibutuhkan ketika mendapati adanya dokumen asing yang menggunakan bahasa asing seperti dalam bahasa Inggris, Jerman, Perancis dan lain sebagainya.

\section{Kesimpulan}

Pewarisan saham kepada ahli waris warga negara asing di Perseroan Terbatas Penanaman Modal Asing tunduk pada hukum yang berlaku di Indonesia, sedangkan penentuan penetapan ahli waris dari pewaris yang merupakan warga negara asing harus mengikuti hukum dari negara yang bersangkutan dan dibuktikan dengan adanya dokumen tertulis yang dikeluarkan oleh lembaga yang berwenang dari negaranya.

Pemberlakuan dokumen asing dalam pewarisan saham di Indonesia harus memenuhi persyaratan sebagaimana diatur dalam Peraturan Menteri Luar Negeri Nomor 09/A/KP/XII/2006/01 yaitu harus dilegalisasi terlebih dahulu di Kedutaan Besar Republik Indonesia sebelum diberlakukan di Indonesia.

\section{Daftar Pustaka}

\section{$\underline{\text { Buku }}$}

Hariyani, Iswi, et all, (2011), Panduan Praktis SABH, Jakarta: Pustaka Yustisia

Purnamasari, Irma Devita, (2012), Kiat-Kiat Cerdas, Mudah, dan Bijak Memahami Masalah Hukum Waris, Jakarta : Kaifa.

Jurnal

Abib, Agus Saiful, Pujiastut, Endah, dan Mulyani, Tri, (2017), Konsep Penanaman Modal Sebagai Upaya Menstimulasi Peningkatan Perekonomian Indonesia, Jurnal Humani,7(1) 
Barus, Zulfadli, (2013), Analisis Filosofis Tentang Peta Konseptual Penelitian Hukum Normatif Dan Penelitian Hukum Sosiologis, Jurnal Dinamika Hukum, 13 (2)

Hapsari, Alya, Priandhini, Liza dan Suyandono, Widodo (2019), Pemberian Akta Hibah Wasiat Atas Seluruh Saham Perseroan PT LNI, Jurnal Fakultas Hukum Universitas Indonesia, 1(2)

Haryono, Wenny Ayu, (2016), Perlindungan Hukum Terhadap Pemegang Saham Minoritas Dalam Peralihan Saham Dengan Akta Pengakuan Hutang, Jurnal IUS, 4(3)

Indah Sari, Ida Ayu Putu Widya dan Ni Wayan Sukeni, (2015), Saham Sebagai Objek Pewarisan Ditinjau Dari Undang-Undang Nomor 40 Tahun 2007 tentang Perseroan Terbatas, Jurnal Kertha Semaya, 3(3)

Savitri, Yuni, (2012), Implementasi Peraturan Pemerintah Terkait Dengan Kepemilikan Saham Dari Modal Asing, Unness Law Journal, 1 (1)

Sebastian, Amadeo Tito dan Adjie Habib, (2018), Hak Ahli Waris Warga Negara Asing Atas Objek Waris Berupa Saham Perseroan Terbatas Penanaman Modal Dalam Negeri, Jurnal Al'Adl, 10 (2)

Subianto, Deri Andrias, dan Asrori, M. Hudi, (2019), Status Perseroan Terbatas Penanaman Modal Asing Akibat Dikabulkannya Pewarganegaraan Para Pemegang Saham, Jurnal Repertorium, 6 (1)

Suryaningtyas, Agustina, (2018), Pelaksanaan Pembagian Warisan Berdasarkan KUHPerdata Berkenaan Dengan Adanya Testamen, Jurnal Daulat Hukum, 1 (1)

Wicaksono, Lucky Suryo, (2016), Kepastian Hukum Nominee Agreement Kepemilikan Saham Perseroan Terbatas, Jurnal Hukum Ius Quia Iustum, 23(1)

Zaharani, Fagustien, (2018), Pewarisan Saham Perseroan Terbatas Kepada Warga Negara Asing Melalui Surat Wasiat, Jurnal Res Judicata, 1(2).

\section{Peraturan Perundang - Undangan}

Kitab Undang-Undang Hukum Perdata.

Undang-Undang Nomor 25 Tahun 2007 tentang Penanaman Modal, Lembaran Negara Republik Indonesia Tahun 2007 Nomor 67, Tambahan Lembaran Negara Republik Indonesia Nomor 4724.

Undang-Undang Nomor 40 Tahun 2007 tentang Perseroan Terbatas, Lembaran Negara Republik Indonesia Tahun 2007 Nomor 106, Tambahan Lembaran Negara Republik Indonesia Nomor 4756.

Peraturan Menteri Luar Negeri Nomor 09/A/KP/XII/2006/01 tentang Panduan Umum Tata Cara Hubungan Dan Kerjasama Luar Negeri Oleh Pemerintah Daerah

Peraturan Menteri Hukum dan Hak Asasi Manusia Nomor 29 Tahun 2016 tentang Syarat dan Tata Cara Pengangkatan, Pelaporan dan Pemberhentian Penerjemah Tersumpah

Peraturan BKPM Nomor 6 Tahun 2018 tentang Pedoman dan Tata Cara Perizinan dan Fasilitas, Berita Negara Republik Indonesia Tahun 2018 Nomor 934 